\title{
Are the energy matrix values of the different feed additives in broiler chicken diets could be summed?
}

\author{
Abdallah E. Metwally', Ahmed A. A. Abdel-Wareth², Ahmed A. Saleh³ and Shimaa A. Amer ${ }^{1 *}$
}

\begin{abstract}
Background: The aim of this study is to investigate whether the energy matrix values of the nonstarch polysaccharide- (NSP-) degrading enzymes, bioemulsifier (LYSOFORTE'), guanidinoacetic acid (CreAMINO ${ }^{\circ}$ ), or their combinations could be summed. The effects of these additives on the growth performance, carcass traits, and economic value of the broiler chicken diets were evaluated. A total of 525-one-day-old Ross chicks with an initial body weight of $42.96 \pm 0.87 \mathrm{~g}$ were haphazardly allocated into seven groups with five replicates. The seven experimental treatments are as follows: (1) basal diet with no additives (breeder recommendation), which is the control group, (2) basal diet minus $100 \mathrm{kcal} / \mathrm{kg}$ supplemented with $0.02 \%$ NSP-degrading enzymes (NSP), (3) basal diet minus $50 \mathrm{kcal} / \mathrm{kg}$ supplemented with $0.025 \%$ emulsifier (LYSOFORTE ${ }^{\circ}$ ), (4) basal diet minus $50 \mathrm{kcal} / \mathrm{kg}$ supplemented with $0.06 \%$ guanidinoacetic acid (CreAMINO ${ }^{\circ}$ ), (5) basal diet minus $150 \mathrm{kcal} / \mathrm{kg}$ supplemented with a mixture of NSP and LYSOFORTE' (NSPL), (6) basal diet minus $100 \mathrm{kcal} / \mathrm{kg}$ supplemented with a mixture of NSP and CreAMINO (NSPC), and (7) basal diet minus $200 \mathrm{kcal} / \mathrm{kg}$ supplemented with a mixture of NSP, LYSO, and CreAMINO ${ }^{\circ}$ (NSPLC). The experiment lasted for 35 days.

Results: It was found that the final body weight, body weight gain, and relative growth rate were significantly higher in birds fed diets supplemented with NSPL, NSPC, CreAMINO, and LYSO with the reduced energy matrix value. The overall feed conversion ratio was significantly improved due to the supplementation of NSPC, CreAMINO, NSPL, and LYSO with the reduced energy matrix value compared to the control group. Moreover, no significant effect on the carcass criteria was observed by the different treatments. As a result of the dietary supplementation with NSPL, NSPC, CreAMINO, and LYSO with the reduced energy matrix value, the net profit, total return, economic efficiency, and performance index were increased and the cost of feed per $\mathrm{kg}$ of body weight gain was decreased.

Conclusion: The energy matrix value of NSPL, NSPC, CreAMINO ${ }^{\circ}$, and LYSOFORTE could be established in the diets of broiler chickens to improve the growth performance and economic efficiency.
\end{abstract}

Keywords: Broiler chickens, Growth performance, Energy matrix value, Natural feed additives

\footnotetext{
* Correspondence: shimaa.amer@zu.edu.eg

${ }^{1}$ Department of Nutrition and Clinical Nutrition, Faculty of Veterinary

Medicine, Zagazig University, Zagazig 44511, Egypt

Full list of author information is available at the end of the article
}

(c) The Author(s). 2020 Open Access This article is licensed under a Creative Commons Attribution 4.0 International License, which permits use, sharing, adaptation, distribution and reproduction in any medium or format, as long as you give appropriate credit to the original author(s) and the source, provide a link to the Creative Commons licence, and indicate if changes were made. The images or other third party material in this article are included in the article's Creative Commons licence, unless indicated otherwise in a credit line to the material. If material is not included in the article's Creative Commons licence and your intended use is not permitted by statutory regulation or exceeds the permitted use, you will need to obtain permission directly from the copyright holder. To view a copy of this licence, visit http://creativecommons.org/licenses/by/4.0/ The Creative Commons Public Domain Dedication waiver (http://creativecommons.org/publicdomain/zero/1.0/) applies to the data made available in this article, unless otherwise stated in a credit line to the data. 


\section{Background}

There is a global demand for chicken meat which continues to increase exponentially [1]; this is partly due to the health claims associated with it, lack of cultural restrictions on its consumption, efficient production, and human population growth [2]. How this expected increase in poultry production will be achieved and what will be the consequences of this change for the sustainability of the production system are the main questions that need answer. The poultry production assured that more improvements in growth rate and store use efficacy can be achieved through genetic selection in the predictable future $[3,4]$. As a consequence of the increased growth rate, birds reach slaughter weight at a later time than before. This has decreased the use of bird resources, and less energy is now needed to maintain body functions due to the shorter growth cycle [5-7]. This improvement in energy efficiency has resulted in a significant reduction in feed consumption of birds, thus improving the environmental sustainability of broiler production. However, it was reported that a higher energy level was more effective in body weight gain (BWG) and morphological parameters rather than the Cobb 500 broiler chicken recommendation, but in the case of feed conversion ratio, a more appropriate energy level was achieved from Cobb 500 broiler chicken recommendation [8].

New feeding practices for poultry include greater accuracy in providing nutrients for optimal growth performance and reducing feed costs and excess nutrients associated with environmental impact [9-14]. According to NRC [15], the standard measure for describing the requirements of energy for poultry and the energy content of diets is the metabolizable energy (ME). The ME is a costly part of poultry diets and it is considered a significant portion of the total cost of producing broiler chicken [16-18]. This supplemental energy requires ME optimization in the diets to decrease feed costs [19]. The level of dietary ME level has a significant role in adjusting the feed efficiency and feed intake in broilers [20]. Several trials have been done to increase the availability of energy for broiler and to raise the accuracy of determining the values of ME of dietary constituent [12, 2126]. The study of Tasirnafas et al. [27] indicated that the highest weight was reported in the ostrich chicks fed on $10 \%$ dietary wastage and $2500 \mathrm{kcal} / \mathrm{kg}$ dietary energy.

Many feed additives like enzymes, emulsifiers, and creatine (CreAMINO) have energy matrix value in poultry feed formulation. Nonstarch polysaccharides (NSPs) are indigestible carbohydrates that result in an increase in the viscosity of the gut digesta and a decrease in the nutrients' availability for digestion due to nutrient enclosure. Nonstarch polysaccharides affect fat digestion more than other nutrients, and the saturated fatty acid digestion is affected more than the unsaturated fatty acids. To overcome the negative effects of these compounds on the growth performance, NSP-degrading enzymes are used. For instance, xylanases and $\beta$-glucanases are used for the degradation of the arabinoxylans and $\beta$-glucans in wheat, rye, barley, and oats and have demonstrated efficiency in improving the nutritional value of these grains for poultry [28]. Therefore, the most important role of supplying enzymes in monogastric animal diets is increasing the concentration of the apparent ME of the feed that consequently has economic benefits. This increase is usually in the range of $50-150 \mathrm{kcal} / \mathrm{kg}$ feed depending on the nature and quality of the ingredients used in the diet and the nature of the used enzyme [29]. NSP-degrading enzymes can reduce the increase in the viscosity of digesta resulting from sugars leaking from the grain cell walls by releasing the nutrients trapped in the feed cellular matrix [30] because the viscosity is larger in smaller birds and decreases with age.

Using an additional energy source in broiler diets represented in fats and oil supplementation is a common practice in the poultry industry. On the other hand, young chicks lack the necessary enzymes needed for effective digestion that improves with age with a significant improvement in the metabolic energy values of lipids in poultry from 1.5 to 3.5 weeks of age $[31,32]$. The most convenient dietary tool to use is lysophospholipids, an absorption enhancer, which can increase emulsification and absorption of fats in the intestine and permit the remodeling of diets to be at the least cost without harming poultry performance [31]. Emulsifiers could play a key role in micelle formation, and lysophospholipids are natural surfactants of hydrolyzed soy lecithin [33].

Guanidinoacetic acid (GAA) is a readily available precursor of creatine, which is synthesized in the kidneys from glycine and L-arginine by L-arginine: glycine amidinotransferase. Next, GAA forms creatine in the liver by the action of guanidinoacetate $N$-methyltransferase. Creatine is a natural component that occurs in the tissues of the animal's body and acts as an important function in energy metabolism as an energy carrier in the cells [34]. It is estimated that about $50 \%$ of creatine required daily is synthesized by the animal whereas the rest must be supplemented by the diet daily. Short-term high-intensity exercise, or repeated bursts of exclusive power, can benefit from creatine supplementation; therefore, the sparing effect of creatine on energy and protein requirement is studied and it is concluded that it has a matrix value of $50 \mathrm{kcal} / \mathrm{kg}$ feed [35]. Furthermore, GAA may be essential for feeding poultry as a substitute for dietary arginine and to maintain the bird's total energy balance [36].

Therefore, this study aimed to investigate whether the energy matrix values of the NSP-degrading enzymes, emulsifier (LYSOFORTE), and GAA (CreAMINO ${ }^{\circ}$ ) or their combinations could be summed or not by assessing 
the effects of their dietary supplementation on the broilers' growth performance, carcass traits, and the economic value of the diets.

\section{Results}

\section{Growth performance}

The effects of NSP-degrading enzymes, LYSO, CreAMINO', and their combinations with the reduced matrix values on the growth performance parameters are shown in Table 1 . Throughout the starter stage, a significant increase $(P<0.05)$ in the growth performance parameters except for the FCR was reported in the birds fed on a diet supplemented with NSPL with its reduced energy matrix value in comparison with the control group. No significant effects $(P>0.05)$ were observed in the BW, BWG, FI, and FCR in the NSP-degrading enzymes, LYSO, CreAMINO, NSPC, and NSPLC groups with their reduced energy matrix value in comparison with the control group. Throughout the grower stage, the BW and
BWG were significantly higher $(P<0.05)$ only in the NSPL group with its reduced energy matrix value. The FI was not significantly affected $(P=0.39)$ by the treatments. The FCR was significantly lower $(P<0.05)$ in the NSPL and NSPC groups. During the finisher period, the dietary supplementation of the LYSO, CreAMINO', NSPL, and NSPC with the reduced energy matrix values resulted in a significant increase $(P<0.05)$ in the bird's BW and BWG and a significant decrease $(P<0.05)$ in the FCR. The final BW, total BWG, and relative growth rate (RGR) were increased significantly $(P<0.01)$ in this order NSPL $>$ NSPC $>$ CreAMINO $>$ LYSO with the reduced energy matrix value. The overall FCR was decreased significantly $(P=0.00)$ in this order NSPC $<$ CreA$\mathrm{MINO}^{\circ}<\mathrm{NSPL}<\mathrm{LYSO}$ with the reduced energy matrix value. No significant differences $(P>0.05)$ in the final $\mathrm{BW}$, total BWG, RGR, and FCR in the NSP-degrading enzymes and NSPLC groups with their reduced energy matrix values in comparison with the control group. The total FI was not significantly differed $(P>0.05)$ by the treatments.

Table 1 The effects of dietary supplementation of NSP-degrading enzymes, LYSOFORTE', CreAMINO ${ }^{\circ}$ and their combination on the growth performance of broiler chickens:

\begin{tabular}{|c|c|c|c|c|c|c|c|c|c|}
\hline Parameter & $\mathrm{T} 1$ & $\mathrm{~T} 2$ & T3 & T4 & T5 & T6 & T7 & SEM & $P$-value \\
\hline Int. Wt. (g) & 42.34 & 42.98 & 42.50 & 43.24 & 43.28 & 43.20 & 43.44 & 0.13 & 0.36 \\
\hline \multicolumn{10}{|c|}{ Starter period } \\
\hline BW (g) & $423.65^{b c}$ & $437.60^{\mathrm{ab}}$ & $415.09^{c}$ & $427.31^{\mathrm{abc}}$ & $446.33^{\mathrm{a}}$ & $429.99^{\mathrm{abc}}$ & $421.60^{b c}$ & 2.88 & 0.05 \\
\hline BWG (g) & $381.31^{b c}$ & $394.61^{\mathrm{ab}}$ & $372.58^{c}$ & $384.07^{\mathrm{abc}}$ & $403.04^{\mathrm{a}}$ & $386.79^{\mathrm{abc}}$ & $378.16^{b c}$ & 2.85 & 0.05 \\
\hline $\mathrm{FI}(\mathrm{g})$ & $465.64^{\mathrm{bc}}$ & $488.01^{\mathrm{ab}}$ & $459.79^{c}$ & $464.02^{\mathrm{bc}}$ & $496.15^{\mathrm{a}}$ & $470.47^{b c}$ & $476.53^{\mathrm{abc}}$ & 3.60 & 0.02 \\
\hline FCR & 1.22 & 1.23 & 1.23 & 1.21 & 1.23 & 1.21 & 1.26 & 0.005 & 0.07 \\
\hline \multicolumn{10}{|c|}{ Grower period } \\
\hline BW(g) & $1073.15^{\mathrm{bc}}$ & $1112.31^{\mathrm{ab}}$ & $1034.32^{c}$ & $1109.44^{\mathrm{abc}}$ & $1159.91^{\mathrm{a}}$ & $1089.62^{\mathrm{abc}}$ & $1065.89^{b c}$ & 10.02 & 0.02 \\
\hline BWG (g) & $649.50^{\mathrm{bc}}$ & $674.71^{\mathrm{abc}}$ & $619.23^{c}$ & $682.12^{\mathrm{ab}}$ & $713.58^{\mathrm{a}}$ & $659.62^{\mathrm{abc}}$ & $644.29^{\mathrm{bc}}$ & 7.51 & 0.03 \\
\hline $\mathrm{Fl}(\mathrm{g})$ & 1062.82 & 1097.29 & 1037.18 & 1067.67 & 1118.65 & 1061.87 & 1073.78 & 9.14 & 0.39 \\
\hline FCR & $1.63^{\mathrm{ab}}$ & $1.62^{\mathrm{ab}}$ & $1.67^{\mathrm{a}}$ & $1.56^{c}$ & $1.57^{c}$ & $1.60^{\mathrm{bc}}$ & $1.66^{\mathrm{a}}$ & 0.008 & 0.001 \\
\hline \multicolumn{10}{|c|}{ Finisher period } \\
\hline BW(g) & $2188.32^{d}$ & $2275.40^{\mathrm{cd}}$ & $2363.88^{b c}$ & $2459.90^{\mathrm{ab}}$ & $2519.21^{a}$ & $2491.28^{\mathrm{ab}}$ & $2275.00^{\mathrm{cd}}$ & 22.72 & 0.001 \\
\hline BWG(g) & $1115.17^{b}$ & $1163.08^{b}$ & $1329.56^{a}$ & $1350.46^{\mathrm{a}}$ & $1359.30^{a}$ & $1401.66^{\mathrm{a}}$ & $2258.22^{b}$ & 20.43 & 0.001 \\
\hline $\mathrm{Fl}(\mathrm{g})$ & 2256.98 & 2302.51 & 2150.40 & 2305.30 & 2365.53 & 2263.14 & 2217.22 & 24.97 & 0.34 \\
\hline FCR & $2.03^{\mathrm{a}}$ & $1.98^{\mathrm{a}}$ & $1.63^{b c}$ & $1.70^{\mathrm{bc}}$ & $1.74^{\mathrm{bc}}$ & $1.61^{\mathrm{c}}$ & $1.83^{\mathrm{ab}}$ & 0.037 & 0.002 \\
\hline \multicolumn{10}{|c|}{ Overall performance } \\
\hline BW(g) & $2188.32^{d}$ & $2275.40^{c d}$ & $2363.88^{b c}$ & $2459.90^{\mathrm{ab}}$ & $2519.21^{a}$ & $2491.28^{\mathrm{ab}}$ & $2275.00^{\mathrm{cd}}$ & 22.72 & 0.001 \\
\hline BWG(g) & $2145.98^{d}$ & $2232.41^{\mathrm{cd}}$ & $2321.38^{\mathrm{bc}}$ & $2416.66^{\mathrm{ab}}$ & $2475.93^{\mathrm{a}}$ & $2448.08^{\mathrm{ab}}$ & $2231.56^{\mathrm{cd}}$ & 22.70 & 0.001 \\
\hline $\mathrm{Fl}(\mathrm{g})$ & 3785.45 & 3853.36 & 3707.48 & 3806.50 & 3980.34 & 3795.49 & 3767.54 & 34.65 & 0.47 \\
\hline FCR & $1.76^{\mathrm{a}}$ & $1.72^{\mathrm{a}}$ & $1.60^{\mathrm{bc}}$ & $1.57^{c}$ & $1.60^{b c}$ & $1.55^{c}$ & $1.68^{\mathrm{ab}}$ & 0.01 & 0.001 \\
\hline$R G R$ & $192.40^{c}$ & $192.58^{\mathrm{bc}}$ & $192.92^{\mathrm{ab}}$ & $193.08^{\mathrm{a}}$ & $193.24^{\mathrm{a}}$ & $193.18^{a}$ & $192.50^{\mathrm{bc}}$ & 0.06 & 0.001 \\
\hline
\end{tabular}

$\mathrm{a}, \mathrm{b}, \mathrm{c}, \mathrm{d}$ Means within the same row carrying different superscripts are significantly different at $(P<0.05)$.

T1: Control group "basal diet with no additives (breeder recommendation (BR)). T2: Basal diet minus $100 \mathrm{kcal} / \mathrm{kg}$ supplemented with $0.02 \%$ NSP-degrading enzymes (NSP). T3: Basal diet minus $50 \mathrm{kcal} / \mathrm{kg}$ supplemented with $0.025 \%$ emulsifier (LYSOFORTE ). T4: Basal diet minus $50 \mathrm{kcal} / \mathrm{kg}$ supplemented with 0.06\% guanidinoacetic acid (CreAMINO ). T5: Basal diet minus $150 \mathrm{kcal} / \mathrm{kg}$ supplemented with a mixture of NSP and LYSOFORTE" (NSPL), T6: Basal diet minus 100 kcal/kg supplemented with a mixture of NSP and CreAMINO (NSPC). T7: Basal diet minus $200 \mathrm{kcal} / \mathrm{kg}$ supplemented with a mixture of NSP, LYSO, and CreAMINO ${ }^{\circ}$ (NSPLC).

$B W$ body weight; $B W G$ body weight gain; $F I$ feed intake; $F C R$ feed conversion ratio; $R G R$ relative growth rate 


\section{Carcass traits}

The effects of NSP-degrading enzymes, LYSOFORTE, CreAMINO ${ }^{\circ}$, and their combinations with the reduced matrix values on the carcass traits relative to the live body weight (\%) are summarized in Table 2 . The results revealed that there were no significant differences $(P>0.05)$ in the weights of breast meat, carcass weight, drumstick, abdominal fat, thigh, liver, gizzard, and proventriculus as a result of the treatments. However, there was a numerical decrease in the abdominal fat $\%$ in LYSOFORTE $^{\circ}$ and CreAMINO groups.

\section{Economic importance}

The economic importance of the diets is shown in Table 3. No significant differences $(P>0.05)$ were reported in feed costs and total costs between the control group and other groups. The total returns were significantly higher in birds fed on diets supplemented with NSPL, NSPC, CreAMINO ${ }^{\circ}$, and LYSO with the reduced energy matrix value $(P<0.05)$. The net profit and performance index were significantly increased $(P<0.01)$ in birds fed on diets supplemented with NSPC, NSPL, CreAMINO ${ }^{\circ}$, and LYSO with the reduced energy matrix value. The economic efficiency was increased significantly $(P<0.01)$ in birds fed on diets supplemented with CreAMINO ${ }^{\circ}$, NSPC, NSPL, and LYSO with the reduced energy matrix value. The cost of feed per $\mathrm{kg}$ of BWG was decreased $(P<0.01)$ in birds fed on diets supplemented with NSPC, NSPL, and $\mathrm{CreAMINO}^{\circ}$ with the reduced energy matrix value. The dietary supplementation with NSPdegrading enzymes and NSPLC with the reduced energy matrix value had no significant effect $(P>0.05)$ on the economic value of the diets.

\section{Discussion}

Rapid growing poultry requires nitrogenous and energetic compounds to support performance and growth. However, contentious problems exist when feeding small birds with large amounts of nutrients [37, 38]. The current study had been done to assess the impact of dietary supplementation of $0.02 \%$ NSP-degrading enzymes, $0.025 \%$ emulsifier (LYSOFORTE ${ }^{\circ}$ ), and $0.06 \%$ creatine (CreAMINO) and their combinations with the reduced energy matrix value on the growth performance of broilers, carcass traits, and the economic value of the diets. The results revealed that the NSPL, NSPC, CreA$\mathrm{MINO}^{\circ}$, and LYSO supplementation with the reduced energy matrix values $(150,100,50$, and $50 \mathrm{kcal} / \mathrm{kg}$ which are lower than the control group, respectively) enhanced the growth performance of the broilers, while matrix values of NSP-degrading enzymes alone or NSPLC did not result in a significant enhancement in the growth performance all over the experimental period. However, the dietary addition of NSP-degrading enzymes with LYSO or CreAMINO led to significantly better performance than that of the control group or the single supplementation. The final BW, BWG, and RGR were increased significantly in NSPL $>$ NSPC $>$ CreAMINO $>$ LYSO with the reduced energy matrix value. The overall FCR was decreased in NSPC $<$ CreAMINO $<$ NSPL $<$ LYSO with the reduced energy matrix value. Similarly, Kocher, et al. [39] reported a significant increase in AME and protein content of SBM-based diets by supplementing an enzyme compound containing multicarbohydrase activities without significant improvement of the birds' growth performance. The results of Meng and Slominski [40] showed that supplementing the corn-SBM diet with a multicarbohydrase mixture of cell walldegrading activities had no consequence on feed intake and BW but improved BWG and FCR. Zanella et al. [41]

Table 2 The effect of dietary supplementation of NSP-degrading enzymes, LYSOFORTE ${ }^{\oplus}$, CreAMINO ${ }^{\circ}$ and their combination on the weight of carcass traits relative to the live body weight (\%):

\begin{tabular}{|c|c|c|c|c|c|c|c|c|c|}
\hline Parameter & T1 & T2 & T3 & T4 & T5 & T6 & T7 & SEM & P-value \\
\hline Carcass weight & 91.69 & 90.73 & 94.38 & 89.97 & 86.99 & 93.25 & 88.49 & 0.87 & 0.27 \\
\hline Breast meat & 28.29 & 24.47 & 26.08 & 25.39 & 28.80 & 27.76 & 27.19 & 0.42 & 0.22 \\
\hline Thighs & 9.70 & 9.66 & 9.41 & 10.17 & 9.24 & 9.52 & 9.84 & 0.19 & 0.97 \\
\hline Drumstick & 9.71 & 10.64 & 9.89 & 11.84 & 10.83 & 10.35 & 13.79 & 0.41 & 0.18 \\
\hline Liver & 2.29 & 1.95 & 2.09 & 2.60 & 1.79 & 2.64 & 2.34 & 0.11 & 0.52 \\
\hline Gizzard & 1.59 & 1.54 & 1.72 & 1.79 & 0.89 & 1.83 & 1.56 & 0.12 & 0.67 \\
\hline Proventriculus & 0.36 & 0.26 & 0.33 & 0.36 & 0.32 & 0.33 & 0.28 & 0.01 & 0.23 \\
\hline Abdominal Fat & 1.82 & 1.60 & 1.39 & 1.16 & 1.62 & 2.04 & 1.47 & 0.09 & 0.39 \\
\hline
\end{tabular}

a,b,c Means within the same row carrying different superscripts are significantly different at $(P<0.05)$.

T1: Control group "basal diet with no additives (breeder recommendation (BR)). T2: Basal diet minus $100 \mathrm{kcal} / \mathrm{kg}$ supplemented with $0.02 \%$ NSP-degrading enzymes (NSP). T3: Basal diet minus $50 \mathrm{kcal} / \mathrm{kg}$ supplemented with 0.025\% emulsifier (LYSOFORTE ). T4: Basal diet minus $50 \mathrm{kcal} / \mathrm{kg}$ supplemented with 0.06\% guanidinoacetic acid (CreAMINO ). T5: Basal diet minus $150 \mathrm{kcal} / \mathrm{kg}$ supplemented with a mixture of NSP and LYSOFORTE" (NSPL), T6: Basal diet minus $100 \mathrm{kcal} / \mathrm{kg}$ supplemented with a mixture of NSP and CreAMINO (NSPC). T7: Basal diet minus $200 \mathrm{kcal} / \mathrm{kg}$ supplemented with a mixture of NSP, LYSO, and CreAMINO ${ }^{\circ}$ (NSPLC). 
Table 3 The effect of dietary supplementation of NSP-degrading enzymes, LYSO, CreAMINO and their combinations on the economic efficiency of the experimental diets:

\begin{tabular}{llllllllll}
\hline Parameter & T1 & T2 & T3 & T4 & T5 & T6 & T7 & SEM & P-value \\
\hline Final BW (kg) & $2.18^{\mathrm{d}}$ & $2.27^{\mathrm{cd}}$ & $2.36^{\mathrm{bc}}$ & $2.45^{\mathrm{ab}}$ & $2.51^{\mathrm{a}}$ & $2.49^{\mathrm{ab}}$ & $2.27^{\mathrm{cd}}$ & 0.02 & 0.001 \\
Feed cost (LE) & 14.76 & 14.52 & 15.06 & 14.22 & 15.20 & 14.57 & 14.44 & 0.12 & 0.290 \\
Total cost (LE) & 22.26 & 22.02 & 22.56 & 21.72 & 22.70 & 22.07 & 21.94 & 0.12 & 0.290 \\
Total return/bird(LE) & $39.38^{\mathrm{d}}$ & $40.95^{\mathrm{cd}}$ & $42.55^{\mathrm{bc}}$ & $44.27^{\mathrm{ab}}$ & $45.34^{\mathrm{a}}$ & $44.84^{\mathrm{ab}}$ & $40.95^{\mathrm{cd}}$ & 0.40 & 0.001 \\
Net profit (LE) & $17.12^{\mathrm{c}}$ & $18.92^{\mathrm{bc}}$ & $19.29^{\mathrm{b}}$ & $22.55^{\mathrm{a}}$ & $22.64^{\mathrm{a}}$ & $22.76^{\mathrm{a}}$ & $19.00^{\mathrm{bc}}$ & 0.40 & 0.001 \\
E. EF. $^{*}$ & $1.16^{\mathrm{c}}$ & $1.30^{\mathrm{bc}}$ & $1.32^{\mathrm{b}}$ & $1.58^{\mathrm{a}}$ & $1.49^{\mathrm{a}}$ & $1.56^{\mathrm{a}}$ & $1.31^{\mathrm{bc}}$ & 0.03 & 0.001 \\
Feed cost/kg gain & $6.89^{\mathrm{a}}$ & $6.65^{\mathrm{a}}$ & $6.74^{\mathrm{a}}$ & $6.14^{\mathrm{bc}}$ & $6.13^{\mathrm{bc}}$ & $5.95^{\mathrm{c}}$ & $6.47^{\mathrm{ab}}$ & 0.07 & 0.001 \\
PI (\%) & $124.39^{\mathrm{c}}$ & $131.28^{\mathrm{bc}}$ & $137.20^{\mathrm{b}}$ & $153.79^{\mathrm{a}}$ & $156.96^{\mathrm{a}}$ & $160.54^{\mathrm{a}}$ & $134.74^{\mathrm{bc}}$ & 2.42 & 0.001 \\
\hline
\end{tabular}

*Economic efficiency, ${ }^{\$}$ Performance index. LE: Egyptian pound.

$\mathrm{a}, \mathrm{b}, \mathrm{c}, \mathrm{d}$ Means within the same row carrying different superscripts are significantly different $\mathrm{at}(P<0.05)$.

T1: Control group "basal diet with no additives (breeder recommendation (BR)). T2: Basal diet minus $100 \mathrm{kcal} / \mathrm{kg}$ supplemented with 0.02\% NSP-degrading enzymes (NSP). T3: Basal diet minus $50 \mathrm{kcal} / \mathrm{kg}$ supplemented with $0.025 \%$ emulsifier (LYSOFORTE ). T4: Basal diet minus $50 \mathrm{kcal} / \mathrm{kg}$ supplemented with 0.06\% guanidinoacetic acid (CreAMINO ). T5: Basal diet minus $150 \mathrm{kcal} / \mathrm{kg}$ supplemented with a mixture of NSP and LYSOFORTE (NSPL), T6: Basal diet minus 100 kcal/kg supplemented with a mixture of NSP and CreAMINO (NSPC). T7: Basal diet minus $200 \mathrm{kcal} / \mathrm{kg}$ supplemented with a mixture of NSP, LYSO, and CreAMINO ${ }^{\circ}$ (NSPLC).

reported a significant improvement in the broilers' growth performance by the supplementation of a marketable enzyme product containing amylase, protease, and xylanase to a corn-SBM diet due to the increase in the ileal digestibility of AME and protein.

The present study showed that the dietary supplementation with CreAMINO ${ }^{\circ}$ alone or in combination with NSP-degrading enzymes with the reduced energy matrix values improved the growth performance of broiler chickens all over the experimental periods. These results can be attributed to the GAA as a precursor to creatine synthesis because more arginine became obtainable for other functions as protein synthesis [42]. Guanidinoacetic acid supplementation has been shown to have sparing effects on arginine, increasing the availability of arginine in broilers [43]. In addition, arginine has an effect on the intestinal morphological features [44]. Therefore, the dietary inclusion of GAA may affect intestinal digestion and nutrient absorption. Fosoul et al. [26] reported improved performance of chickens fed low ME diet with supplemental GAA probably via improved dietary NEp. They suggested that including GAA in diets with lower energy content might improve the overall body energy retention such as fats or proteins which contribute to the well understanding of energy use in broiler chickens. Michiels et al. [45] reported an improved FCR and average daily gain all over the experimental period and increased breast meat yield in groups supplemented with GAA in comparison with the control birds. Also, Lemme et al. [46] reported that guanidinoacetic acid (GAA) resulted in improvement of the bird performance and it was optimal between $0.06 \%$ and $0.12 \%$ supplemented GAA due to the vital role of GAA supplementation in energy metabolism that increased the muscle concentration of creatine and creatine phosphate: ATP ratio.
Abudabos et al. [35] reported a significant improvement in FCR all over the experimental periods by supplementing the low-energy diets with CreAMINO, and the greatest performance was recorded for the diet with $50 \mathrm{kcal} / \mathrm{kg}$ lower ME. Dilger et al. [36] reported similar results of the gain and gain/feed when GAA and creatine were added to the semipurified and practical-type diets.

Various factors influence the lipid digestibility in birds, and these include the saturation degree [47], the free fatty acids levels [48], and the position of the fatty acid in the triglyceride molecule [49]. Also, fat digestion may be influenced by metabolic and physiological factors that depend on the bile salts' surfactant action for the emulsification process. Though baby chicks have inadequate amounts of bile salts resulting in poor fat utilization, this significantly enhanced fat utilization from 1.5 to 3.5 weeks of age [32, 50-52]. Therefore, many experiments have interested in supplementing emulsifiers or bile salts to enhance fat utilization. Our results revealed a nonsignificant effect of LYSOFORTE $^{\circ}$ on the growth performance of broilers during the starter stage but it had an improving effect on the overall performance. However, the combination of NSPdegrading enzymes and LYSOFORTE ${ }^{\circ}$ improved the BW and BWG throughout the starter stage and all over the period. These positive effects may be due to the increase in the digestibility of fatty acids [53]. LYSOFORTE formed smaller and more stable micelles than other emulsifiers such as lecithin [54], and this is a major factor influencing the absorption of lipid and lipophilic substances [55]. Lysophospholipids have been reported to improve intestinal permeability to macromolecules such as dextrans and proteins [56], affect the protein channels formation [57], regulate the activity of various enzymes [58], and cause hypertrophy of the epithelial cells in broiler duodenum [59]. Zhang et al. [53] showed that LYSOFORTE 
supplementation resulted in an improvement in growth performance during the starter period. Melegy et al. [31] reported an improving effect of LYSOFORTE Booster to the lowered performance induced by a negative control diet. The study of Jansen et al. [60] showed a high ME due to the utilization of lysophospholipids in the feed of broiler chickens. Zhao and Kim [61] showed increased BWG and lower FCR in broiler chickens fed diets supplemented with lysophospholipids compared to nonsupplemented diets. Also, a low-energy diet supplemented with emulsifier and multienzymes partially improved the growth performance and hence correct the depressing effects of the low-energy diets in broilers [62, 63]. Zampiga et al. [64] suggested that the use of lysophospholipids can improve the feed efficiency of broiler chickens.

The improvements of NSPL, NSPC, LYSO, and CreAMINO supplementation on the performance of broilers were reflected in the economic value of the diets where the total return was increased in NSPL, NSPC, CreA$\mathrm{MINO}^{\circ}$, and LYSO. The net profit and performance index were significantly increased in NSPC, NSPL, CreAMINO, and LYSO. The economic efficiency was increased in CreAMINO', NSPC, NSPL, and LYSO with the reduced energy matrix value. The cost of feed per $\mathrm{kg}$ of BWG was decreased significantly in NSPC, NSPL, and CreAMINO with the reduced energy matrix value. Similar results were obtained in the study of Amer, et al. [12] who reported improved economic efficiency by supplementing the lowenergy diet with the alpha-galactosidase enzyme.

Regarding the effect of dietary supplementation of NSP-degrading enzymes, LYSOFORTE, CreAMINO', and their combinations with the reduced matrix values on the carcass traits, the results revealed nonsignificant effects of these additives on the relative weights of breast meat, carcass weight, drumstick, thigh, liver, gizzard, and proventriculus. There was a numerical decrease in the abdominal fat weight in LYSOFORTE ${ }^{\circ}$ and CreAMINO groups. Similarly, Zhao and Kim [61] reported decreased abdominal fat weight in lysophospholipid-supplemented groups compared to the basal diet. Also, Zhang [65] reported decreased abdominal fat percentage in broiler chickens fed diets that contained varying levels of emulsifiers at $0.02,0.035,0.05$, and $0.065 \%$ on day 42 which give evidence that emulsifiers can increase the body fat cycle and improve the deposition of muscle fats. Zampiga et al. [64] showed that lysophospholipids had a limited effect on carcass traits of broiler chickens. The results of Metwally et al. [66] showed increased carcass dressing and decreased abdominal fat as a result of CreAMINO supplementation in broiler chicken diets.

\section{Conclusions}

Dietary supplementation with CreAMINO ${ }^{\circ}$ or LYSOFORTE $^{\circ}$ or the mixture of NSP-degrading enzyme with
CreAMINO ${ }^{\circ}$ or with LYSOFORTE ${ }^{\circ}$ with the reduced energy matrix value of 50,50,100, and $150 \mathrm{kcal} / \mathrm{kg}$ lower than the breeder recommendation, respectively, can improve the final body weight, body weight gain, feed conversion ratio, and the relative growth rate of broiler chickens and can increase the economic efficiency of their supplemented diets.

\section{Methods \\ Birds}

A total of 525-one-day-old broiler chicks (Ross 308 broiler) with an initial body weight of $42.96 \pm 0.87 \mathrm{~g}$ were obtained from a commercial chick producer (Dakahlia Poultry, Mansoura, Egypt) and used in the experiments. The experiment was carried out at the experimental station of the Faculty of Veterinary Medicine, Zagazig University, Egypt. The experimental protocol was approved by the Ethics of the Institutional Animal Care and Use Committee of Zagazig University, Egypt (ZUIACUC-2019), and all animal experiments were performed in accordance with the recommendations described in "The Guide for the Care and Use of Laboratory Animals in Scientific Investigations". The replicate number and treatment group were visible at each pen. The maximum number of birds per pen and space per bird, respectively, followed the current legislation. The birds were housed in pens with 15 birds each. Feed and water were supplied for ad libitum consumption. Pens were equipped with feeders and drinkers. The temperature and lighting regime followed the breeder's recommendation. All pens were checked daily for general health status and whether there were sick and dead birds. Standard health and vaccination practices were done against New Castle (at the 4th and 14th days) and Gumboro diseases (at the 7th and 22 days). After the study, all remaining birds were released.

\section{Investigated feed additives}

The used feed additives were as follows: (1) nonstarch polysaccharide- (NSP-) degrading enzymes, in a commercial form AveMix XG 10 (AVEVE Biochem, Merksem, Belgium), which is a multienzyme concept with high glucanase and high xylanase activity, designed for monogastric feeds (active substances: endo-1,3 (4)- $B$ glucanase; endo-1,4- $\beta$-xylanase and cellulase); (2) bioemulsifier in a commercial form LYSOFORTE (Kemin Industries, Inc., USA); and (3) GAA in a commercial form CreAMINO ${ }^{\circ}$ (AlzChem, Trostberg, Germany).

\section{Diets and experimental design}

Birds were randomly allocated into seven treatments with five replicates (15 chicks/ replicate). The seven treatments are as follows: (1) basal diet with no additives (breeder recommendation) which is the control group, 


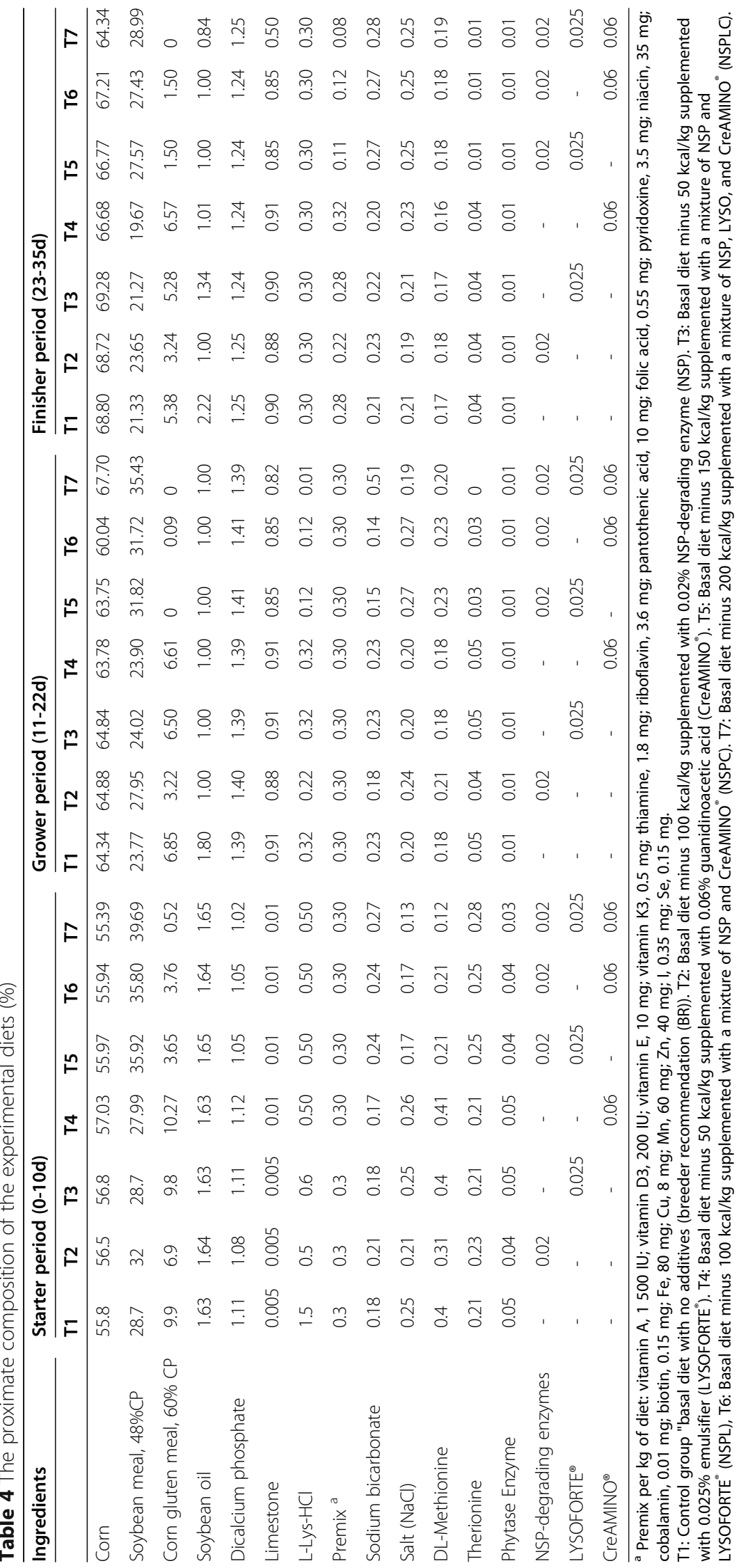




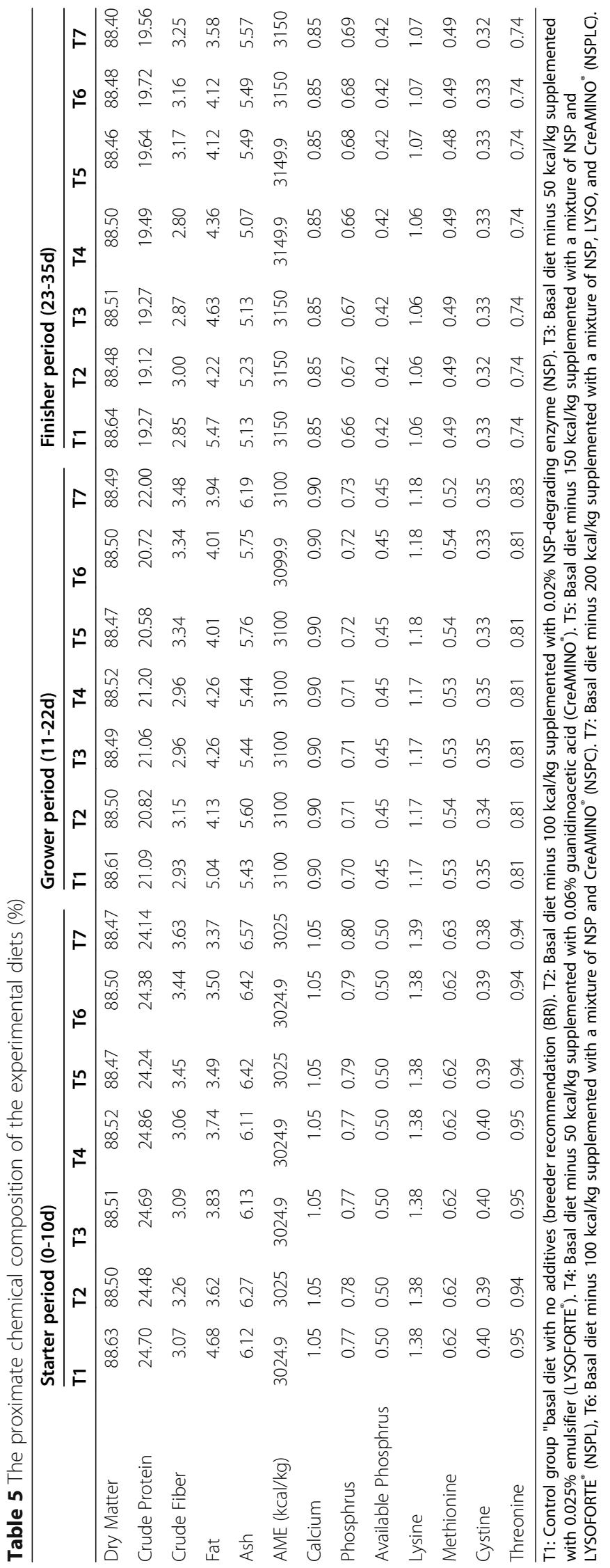


(2) basal diet minus $100 \mathrm{kcal} / \mathrm{kg}$ supplemented with $0.02 \%$ NSP-degrading enzymes (NSP), (3) basal diet minus $50 \mathrm{kcal} / \mathrm{kg}$ supplemented with $0.025 \%$ emulsifier (LYSOFORTE), (4) basal diet minus $50 \mathrm{kcal} / \mathrm{kg}$ supplemented with $0.06 \%$ guanidinoacetic acid (CreAMINO), (5) basal diet minus $150 \mathrm{kcal} / \mathrm{kg}$ supplemented with a mixture of NSP-degrading enzymes and LYSOFORTE (NSPL), (6) basal diet minus $100 \mathrm{kcal} / \mathrm{kg}$ supplemented with a mixture of NSP-degrading enzymes and CreA$\mathrm{MINO}^{\circ}$ (NSPC), and (7) basal diet minus $200 \mathrm{kcal} / \mathrm{kg}$ supplemented with a mixture of NSP-degrading enzymes, LYSO, CreAMINO', and NSPLC. The experiment lasted for $35 \mathrm{~d}$. The experiment was divided into three periods including the starter period $(0-10 \mathrm{~d})$, the grower period (11-22 d), and the finisher period (23-35 d). The proximate composition and chemical composition of the experimental diets are shown in (Tables 4 and 5) based on a corn-soybean meal, and they were formulated to follow the Ross Manual Guide [67]. The feed was offered to the birds in pelleted physical feed form in the whole period (starter, grower, and finisher).

\section{Growth performance}

The initial body weight of the one-day-old chick was recorded on arrival, and then birds were weighed at the end of each stage at 11,22, and 35th days of age. Bodyweight gain was calculated as the difference between the final body weight during the intended period and the initial weight during the same period. Feed intake of each replicate was recorded as the difference between the feed offered weight and residues left and then divided by the number of birds in each replicate to determine the average feed intake per bird. The feed conversion ratio (FCR) was estimated at the end of each stage [68]: FCR = amount of feed consumed (g)/BWG (g). The relative growth rate (RGR) was calculated at the end of the experiment using the following equation [69]:

\section{Carcass traits}

At the end of the experiment, five birds per group (one bird /replicate) were randomly selected and fasted for $12 \mathrm{~h}$ with a free water supply, and then euthanized by cervical dislocation according to the American Veterinary Medical Association guidelines for the euthanasia of animals, AVMA [70] for carcass evaluation (e.g., carcass weight, breast meat weight, and abdominal fat pad).

\section{Economic importance}

Collective efficiency measures were calculated according to El-Telbany and Atallah [71] and Dunning and Daniels [72]. They include the total return, total costs, variable costs, and net profit. The performance index (PI) was calculated according to North and Bell [73].

Total return (LE)/bird = price of $\mathrm{kg} \times$ live body weight $/$ bird.

Total costs $(\mathrm{LE})=$ fixed $\operatorname{costs}+$ variable costs $($ feed cost, LE).

Net profit $(L E)=$ total returns - total costs.

Economic efficiency $(\mathrm{EEF})=$ net profit $(\mathrm{LE}) /$ total feed cost (LE).

Feed cost $/ \mathrm{kg}$ gain $=$ total feed cost $/$ total weight gain .

Performance index \% (PI) = final live body weight $(\mathrm{kg}) /$ feed conversion $\times 100$.

\section{Statistical analysis}

Shapiro-Wilk's test was used to verify the normality and Levene's test was used to verify homogeneity of variance components between experimental treatments and the assumption were achieved ( $p>0.05)$. One-Way ANOVA was used to investigate the effect of dietary supplementation of NSP-degrading enzymes (NSP), emulsifier (LYSOFORTE), and creatine (CreAMINO) and their combinations with the reduced energy matrix value on the broilers' growth performance, carcass traits, and the economic value of the diets using SPSS version 17 for Windows (SPSS, Inc., Chicago, IL, USA). The sample size used in this study was determined in line with existing research [12]. Duncan's multiple range test was used to compare the differences between the means test [74] and the variation in the data was expressed as pooled SEM, and the significance level was set at $P<0.05$.

\section{Abbreviations}

NSP: Nonstarch polysaccharides; LYSO: LYSOFORTE ; Creatine: CreAMINO ; NSPL: A mixture of NSP and LYSOFORTE; ; NSPC: A mixture of NSP and CreAMINO ; NSPLC: A mixture of NSP, LYSO, and CreAMINO;

GAA: Guanidinoacetic acid; ME: Metabolizable energy; BW: Body weight; BWG: Body weight gain; Fl: Feed intake; FCR: Feed conversion ratio;

RGR: Relative growth rate; LE: Egyptian pound

\section{Acknowledgments}

Not applicable

\section{Authors' contributions}

The design of the experiment was done by AEM and SAA; methodology, AEM, SAA, AAA, and AAS; data collection and analysis, AEM and SAA; writing of the manuscript, AEM and SAA. All authors have read and approved the manuscript.

\section{Funding}

This research did not receive any specific grant from funding agencies in the public, commercial, or not-for-profit sectors.

Availability of data and materials

The datasets used and analyzed during the current study are available from the corresponding author on reasonable request.

\section{Ethics approval and consent to participate}

The experimental protocol was approved by the Ethics of the Institutional Animal Care and Use Committee of Zagazig University, Egypt (ZUIACUC2019), and all animal experiments were performed in accordance with recommendations described in "The Guide for the Care and Use of Laboratory Animals in Scientific Investigations". 


\section{Consent for publication}

Not applicable.

\section{Competing interests}

The authors declare that they have no conflicts of interest.

\section{Author details}

'Department of Nutrition and Clinical Nutrition, Faculty of Veterinary Medicine, Zagazig University, Zagazig 44511, Egypt. ${ }^{2}$ Department of Animal and Poultry Production, Faculty of Agriculture, South Valley University, Qena 83523, Egypt. ${ }^{3}$ Department of Poultry Production, Faculty of Agriculture, Kafr Elsheikh University, Kafr Elsheikh 33516, Egypt.

\section{Received: 11 May 2020 Accepted: 30 September 2020} Published online: 15 October 2020

\section{References}

1. Alexandratos N, Bruinsma J: World agriculture towards 2030/2050: the 2012 revision. 2012

2. Magdelaine P, Spiess M, Valceschini E. Poultry meat consumption trends in Europe. World's Poul Sci J. 2008;64(1):53-64.

3. Leinonen I, Williams A, Kyriazakis I. Potential environmental benefits of prospective genetic changes in broiler traits. Poul Sci. 2016;95(2):228-36. .

4. Leinonen I, Kyriazakis I. How can we improve the environmental sustainability of poultry production? Proceed Nut Soc. 2016;75(3):265-73. .

5. Tallentire C, Leinonen I, Kyriazakis I. Artificial selection for improved energy efficiency is reaching its limits in broiler chickens. Scientific reports. 2018; $8(1): 1-10$.

6. Tallentire CW, Leinonen I, Kyriazakis I. Breeding for efficiency in the broiler chicken: A review. Agron Sustain Dev. 2016:36(4):66.

7. Emmans G. Effective energy: a concept of energy utilization applied across species. Br J Nut. 1994;71(6):801-21.

8. Ghahremani A, Sadeghi A, Hesaraki S, Chamani M, Shawrang P. Energy Type and Amount in the Diets of Broiler Chickens: Effects on Performance and Duodenal Morphology. Iran J Appl Anim Sci. 2016;6(4):909-15.

9. Amer SA, Omar AE, El-Hack MEA. Effects of selenium-and chromiumenriched diets on growth performance, lipid profile, and mineral concentration in different tissues of growing rabbits. Bio Trace Element Res. 2019;187(1):92-9.

10. Amer SA, Omar AE, Mohamed WA, Gharib HS, El-Eraky WA. Impact of Betaine Supplementation on the Growth Performance, Tonic Immobility, and Some Blood Chemistry of Broiler Chickens Fed Normal and Low Energy Diets During Natural Summer Stress. Zag Vet J. 2018;46(1):37-50.

11. Amer SA, Kishawy AT. ELseddawy NM, El-Hack MEA: Impacts of bentonite supplementation on growth, carcass traits, nutrient digestibility, and histopathology of certain organs of rabbits fed diet naturally contaminated with aflatoxin. Environ Sci and Poll Res. 2018;25(2):1340-9. .

12. Amer SA, Naser MA, Abdel-Wareth AA, Saleh AA, Elsayed SA. Abdel fattah DM, Metwally AE: Effect of dietary supplementation of alphagalactosidase on the growth performance, ileal digestibility, intestinal morphology, and biochemical parameters in broiler chickens. BMC Vet Res. 2020;16:1-13.

13. A Gouda, SA Amer, S Gabr, SA Tolba: Effect of dietary supplemental ascorbic acid and folic acid on the growth performance, redox status, and immune status of broiler chickens under heat stress. Trop. Anim. Heal. Prod.2020, 1-10.

14. Omar A, Al-khalaifah HS, Mohamed W, Gharib H, Osman A, Algabri NA, Amer SA. Effects of Phenolic-Rich Onion (Allium cepa L.) Extract On the Growth Performance, Behavior, Intestinal Histology, Amino Acid Digestibility, Antioxidant Activity, and the Immune Status of Broiler Chickens. Front Vet Sci. 2020:7:728.

15. NRC: Nutrient requirements of poultry. Washington, DC, National Academic Press) ORTIZ, LT, REBOLÉ, A, ALZUETA, C, RODRÍGUEZ, ML \& TREVIÑO, J, 2001 Metabolisable energy value and diges-tibility of fat and fatty acids in linseed determined with growing broiler chickens British Poul Sci 1994425763.

16. Attia Y, Abd El-Hamid A, Abdallah A, Berikaa M, El-Gandy M, Sahin K, Abou-Shehema B: Effect of betaine, vitamin $C$ and vitamin $E$ on egg quality, hatchability, and markers of liver and renal functions in dualpurpose breeding hens exposed to chronic heat stress. Eur.Poul. Sci. $2018,82$.
17. Al-Harthi MA, Attia YA, Al-Sagan AA, Elgandy MF. Nutrients profile, protein quality and energy value of whole prosopis pods meal as a feedstuff for poultry feeding. Sci: Ital. J. Anim; 2018.

18. Hassan SS, Attia Y, Abd-El-Hamid E, Nagadi SA, El-ashry A. Impact of increasing dietary oil concentrations with a constant energy level on the tolerance of broiler chickens to a high ambient temperature. Revista Mexicana de Ciencias Pecuarias. 2018;9(2):220-39.

19. Pesti G, Bakalli R, Qiao M, Sterling K. A comparison of eight grades of fat as broiler feed ingredients. Poul Scie. 2002;81(3):382-90.

20. Lopez G, Leeson S. Review: energy partitioning in broiler chickens. Can J Anim Sci. 2008;88(2):205-12.

21. Dale N, Fuller H. Correlation of protein content of feedstuffs with the magnitude of nitrogen correction in true metabolizable energy determinations. Poult Scie. 1984;63(5):1008-12.

22. Farrell D. Rapid determination of metabolisable energy of foods using cockerels. Br Poult Sci. 1978;19(3):303-8.

23. McNab J, Blair J. Modified assay for true and apparent metabolisable energy based on tube feeding. Bri Poult Sci. 1988;29(4):697-707.

24. Sibbald I. A bioassay for true metabolizable energy in feedingstuffs. Poult Sci. 1976;55(1):303-8.

25. Sibbald I. The effect of the duration of the excreta collection period on the true metabolizable energy values of feedingstuffs with slow rates of passage. Poult Sci. 1979;58(4):896-9.

26. Fosoul SSAS, Azarfar A, Gheisari A, Khosravinia H. Energy utilisation of broiler chickens in response to guanidinoacetic acid supplementation in diets with various energy contents. Bri J Nut. 2018;120(2):131-40. .

27. Tasirnafas M, Seidavi A, Rasouli B, Kawka M. Effect of vegetable wastage and energy in ostrich chick diet on performance and hematology. Trop Anim Health Prod. 2015:47(6):1017-26.

28. Raza A, Bashir S, Tabassum R. An update on carbohydrases: growth performance and intestinal health of poultry. Heliyon. 2019;5(4):e01437.

29. Adeola O, Cowieson A. Board-invited review: opportunities and challenges in using exogenous enzymes to improve nonruminant animal production. J Anim Sci. 2011;89(10):3189-218.

30. Moftakharzadeh SA, Moravej $H$, Shivazad M. Effect of using the Matrix Values for NSP-degrading enzymes on performance, water intake, litter moisture and jejunal digesta viscosity of broilers fed barley-based diet. Acta Scient Anim Sci. 2017:39(1):65-72.

31. Melegy $T$, Khaled N, El-Bana R, Abdellatif H. Dietary fortification of a natural biosurfactant, lysolecithin in broiler. Afri J Agri Res. 2010;5(21):2886-92. .

32. Wiseman J, Salvador F. Influence of age, chemical composition and rate of inclusion on the apparent metabolisable energy of fats fed to broiler chicks. Br Poult Sci. 1989:30(3):653-62.

33. Joshi A, Paratkar SG, Thorat BN. Modification of lecithin by physical, chemical and enzymatic methods. Eur J Lipid Sci Tech. 2006;108(4): 363-73.

34. Walker JB. Creatine: biosynthesis, regulation, and function. Adv Enzymol Relat Areas Mol Biol. 1979;50:177-242.

35. Abudabos AM, Saleh F, Lemme A, Zakaria HA. The relationship between guanidino acetic acid and metabolisable energy level of diets on performance of broiler chickens. Ital J Anim Sci. 2014;13(3):3269.

36. Dilger RN, Bryant-Angeloni K, Payne R, Lemme A, Parsons CM. Dietary guanidino acetic acid is an efficacious replacement for arginine for young chicks. Poul Sci. 2013;92(1):171-7.

37. Widyaratne G, Drew M. Effects of protein level and digestibility on the growth and carcass characteristics of broiler chickens1. Poul Sci. 2011;90(3): 595-603.

38. Rochell S, Helmbrecht A, Parsons CM, Dilger RN. Influence of dietary amino acid reductions and Eimeria acervulina infection on growth performance and intestinal cytokine responses of broilers fed low crude protein diets. Poul Sci. 2016;95(11):2602-14.

39. Kocher A, Choct M, Porter M, Broz J. Effects of feed enzymes on nutritive value of soyabean meal fed to broilers. Bri Poul Sci. 2002;43(1):54-63.

40. Meng X, Slominski B. Nutritive values of corn, soybean meal, canola meal, and peas for broiler chickens as affected by a multicarbohydrase preparation of cell wall degrading enzymes. Poul Sci. 2005;84(8):1242-51.

41. Zanella I, Sakomura N, Silversides F, Fiqueirdo A, Pack M. Effect of enzyme supplementation of broiler diets based on corn and soybeans. Poul Sci. 1999;78(4):561-8.

42. Edwards $\mathrm{H} \mathrm{Jr}$, Young $\mathrm{R}$, Gillis M. Studies on arginine deficiency in chicks. J Nut. 1958;64(2):271-9. 
43. Baker $\mathrm{DH}$. Advances in protein-amino acid nutrition of poultry. Amino Acids. 2009;37(1):29-41.

44. Khajali F, Moghaddam MH, Hassanpour H. An L-arginine supplement improves broiler hypertensive response and gut function in broiler chickens reared at high altitude. Inte J Biomet. 2014;58(6):1175-9.

45. Michiels J, Maertens L, Buyse J, Lemme A, Rademacher M, Dierick N, De Smet S. Supplementation of guanidinoacetic acid to broiler diets: effects on performance, carcass characteristics, meat quality, and energy metabolism. Poul Sci. 2012;91(2):402-12.

46. Lemme A, Ringel J, Rostagno H, Redshaw M: Supplemental guanidino acetic acid improved feed conversion, weight gain, and breast meat yield in male and female broilers. In: Proceedings of the 16th Euro. Symp. Poul. Nut:: 2007; 2007: 335-338.

47. Leeson S, Summers J: Fat ME values: the effect of fatty acid saturation. Feedstuffs 1976.

48. Vila B, Esteve-Garcia E: Studies on acid oils and fatty acids for chickens. II. Effect of free fatty acid content and degree of saturation of free fatty acids and neutral fat on fatty acid digestibility. Br. Poul.Sci. 1996, 37(1):119-130.

49. Renner R, Hill F. Factors affecting the absorbability of saturated fatty acids in the chick. J Nut. 1961;74(3):254-8.

50. Carew L Jr, Machemer R Jr, Sharp R, Foss D. Fat absorption by the very young chick. Poul Sci. 1972;51(3):738-42. .

51. C Freeman: Digestion, absorption and transport of fats--non-ruminants. Proceedings-Easter School in Agricultural Science, University of Nottingham 1984

52. Krogdahl Å. Digestion and absorption of lipids in poultry. J Nut. 1985;115(5): 675-85.

53. Zhang B, Haitao L, Zhao D, Guo Y, Barri A. Effect of fat type and lysophosphatidylcholine addition to broiler diets on performance, apparent digestibility of fatty acids, and apparent metabolizable energy content. Anim Feed Sci Technol. 2011;163(2-4):177-84.

54. Schwarzer K, Adams CA. The influence of specific phospholipids as absorption enhancer in animal nutrition. Lipid/Fett. 1996;98(9):304-8. .

55. Reynier M, Lafont H, Crotte C, Sauve P, Gerolami A. Intestinal cholesterol uptake: comparison between mixed micelles containing lecithin or lysolecithin. Lipids. 1985;20(3):145-50.

56. Tagesson C, Franzen L, Dahl G, Weström B. Lysophosphatidylcholine increases rat ileal permeability to macromolecules. Gut. 1985;26(4):369-77.

57. Lundbaek JA, Andersen OS. Lysophospholipids modulate channel function by altering the mechanical properties of lipid bilayers. J of General Physiol. 1994;104(4):645-73.

58. Shier WT, Baldwin JH, Nilsen-Hamilton M, Hamilton RT, Thanassi NM Regulation of guanylate and adenylate cyclase activities by lysolecithin. Proceed o Nat Acad Sci. 1976;73(5):1586-90.

59. Khonyoung D, Yamauchi K, Suzuki K. Influence of dietary fat sources and lysolecithin on growth performance, visceral organ size, and histological intestinal alteration in broiler chickens. Livestock Sci. 2015;176:111-20.

60. Jansen M, Nuyens F, Buyse J, Leleu S, Van Campenhout L. Interaction between fat type and lysolecithin supplementation in broiler feeds. Poul Sci. 2015;94(10):2506-15.

61. Zhao P, Kim I. Effect of diets with different energy and lysophospholipids levels on performance, nutrient metabolism, and body composition in broilers. Poul Sci. 2017;96(5):1341-7.

62. Cho JH, Zhao P, Kim $\mathbb{H}$. Effects of emulsifier and multi-enzyme in different energy densitydiet on growth performance, blood profiles, and relative organ weight in broiler chickens. J Agri Sci. 2012;4(10):161. .

63. Wang JP, Zhang ZF, Yan L, Kim IH. Effects of dietary supplementation of emulsifier and carbohydrase on the growth performance, serum cholesterol and breast meat fatty acids profile of broiler chickens. Animal Science Journal. 2016;87(2):250-6.

64. Zampiga M, Meluzzi A, Sirri F. Effect of dietary supplementation of lysophospholipids on productive performance, nutrient digestibility and carcass quality traits of broiler chickens. Ital J Anim Sci. 2016;15(3): 521-8.

65. Zhang Q. Effects of emulsifier on nutrients utilization, growth performance, and meat quality in broilers. China: Master Diss Shandong Agricultural Univ Shandong; 2010.

66. Metwally A, Ibrahim D, Khater SI. Effects of supplementing broiler diets with CreAMINO ${ }^{\circledast}$ on broiler performance, carcass traits and the expression of muscle growth related genes. Research Opinions in Animal and Veterinary Sciences. 2015;5(11):435-42.
67. AVIAGEN R: Ross Broiler Management Manual, 2009. http://pt aviagen com/ assets/Tech_Cen ter/Ross_Broiler/Ross_Broiler_Manual_2014, 9:350-364.

68. Wanger D, Furrow R, Bradly B. Sub chronic toxicity of growth promoters in broiler chickens. Vet Path. 1983;20:253-359.

69. Brody S: Bioenergetics and growth: with special reference to the efficiency complex in domestic animals. Bioenergetics and growth: with special reference to the efficiency complex in domestic animals 1945.

70. AVMA: American Veterinary Medical Association guidelines for the euthanasia of animals guidelines for the euthanasia of animals, 2013 edition Am. Vet. Med. Assoc Schaumburg, IL 2013.

71. El-Telbany $\mathrm{M}$, Atallah S: Some culture factors affecting the productive and economic efficiency of Mugil capito nursing in earthen pond system 9 th Scientific Cingrees. Fac of Vet Med Assiut Univ 2000:19-20.

72. R Dunning, $H$ Daniels: Hybrid striped bass production in ponds: enterprise budget: Southern Regional Aquaculture Center; 2001.

73. North M, Bell D. Breeder management. Connecticut: Commercial Chicken Production Manual The Avi Publishing Company Inc Westport; 1984. p. 240-321.

74. Duncan DB. Multiple range and multiple F tests. Biometrics. 1955;11(1):1-42.

\section{Publisher's Note}

Springer Nature remains neutral with regard to jurisdictional claims in published maps and institutional affiliations.
Ready to submit your research? Choose BMC and benefit from:

- fast, convenient online submission

- thorough peer review by experienced researchers in your field

- rapid publication on acceptance

- support for research data, including large and complex data types

- gold Open Access which fosters wider collaboration and increased citations

- maximum visibility for your research: over $100 \mathrm{M}$ website views per year

At BMC, research is always in progress.

Learn more biomedcentral.com/submissions 